\title{
Globalization and equestrian culture: the case of Equitation in the French Tradition.
}

\author{
Sylvine Pickel-Chevalier, Associate Professor, ESTHUA, University of Angers, France, \\ Laboratory ESO CNRS UMR 6590.
}

\section{Introduction}

In 2011 the French riding tradition was listed by UNESCO as an example of the Intangible Cultural Heritage of Humanity. This listing challenges the notions of heritage and culture, but also the complex balance between local and global scales. France has, like many other countries, an ancient equestrian culture which is still alive and well, encouraged by various international and local influences and sometimes conflicting ideas. Its inclusion in the western society of leisure and consumption deeply influenced by the American model, in the second half of the twentieth century, upset its ancestral utilitarian functions, redefining horses and riding within the prism of a pleasure-seeking, sporting and emotional relationship. This raised questions about what constitutes the French equestrian culture which is protected today, in the more general landscape of globalization. How is it constructed and how is it defined today within a progressive society, combining resistance and the assimilation of new national and international trends?

The inclusion of the French riding tradition as part of UNESCO's intangible heritage was particularly aimed at preserving it from the danger of " standardization' driven by sporting competitions and their rules" as the Ministry of Culture makes clear (http://insitu.revues.org/9675). This process is part of a pattern of broader thinking, referring to relations between building a living heritage at a local level and globalization, defined as the global integration of economic, financial, ecological and cultural phenomena. Far from strictly opposing it, we can see that the global system creates the need for recognition and identification, favoring intellectualization, innovation and the re-adoption of heritage (Dollflus, 2007; Lévy (ed), 2008).

The case of the French riding tradition listed by UNESCO as a form of intangible heritage places this process of interactions between local and global, raising several questions: first, we can question on which equestrian cultures this French 'tradition' is based, combining assimilation, resistance and invention, tracing the key moments of its history built on the foundations of five centuries of evolution (Digard, 2007; Roche, 2011; Henry \& Oussedik, 2014; Franchet d'Espèrey, 2011). With this knowledge, highlighting the non-homogeneous nature of French equestrian culture and supported by various national and international influences, I examine the cultural revolution with which it has interacted throughout the $20^{\text {th }}$ century, particularly under American influence; it has significantly transformed the relationship with the horse, while riding continues to be part of our leisure and consumption society (PickelChevalier and Grefe, 2015).

This recent process of change then leads me to study the heritage-creation process which has ushered the French riding tradition arrived into the $21^{\text {st }}$ century, through a dialectic that combines the building of a national collective memory that induces choices (Babelon and Chastel, 1994; Sire, 1996; Heinich, 2009) and the need for international accessibility. In this context, I also explore the relations between heritage and sport and leisure, contributing to their revaluation and reconstruction (Richard, 1996; Smith, 2009; Lazzarotti, 2011), which may include reinvention of tradition (Thompson, 2010; Hobsbawm et Ranger, 2012). 
My methodology combines diachronic and synchronic approaches to analyze the construction of a French riding tradition, based on a study of French equestrian culture in its complex relationship with globalization. This chapter uses four different forms of data:

- Historiographic material on the centuries-old French equestrian culture;

- Contemporary statistics from the French Equestrian Federation (FFE) and from the French Institute for Horses and Horse Riding (IFCE);

- In-depth interviews with five key managers of French equestrian and cultural institutions, and economic partners within the equestrian sector, including the General Director of Heritage, Director of Research and Scientific Policy at the French Ministry of Culture and Communication, Pascal Lièvaux (October 2013); the Director of the Resource Centre at the National Riding School (ENE)/Cadre Noir de Saumur (IFCE), Bernard Maurel (May 2016); the President of Agir-Sport and Coordinator for Outdoor Sports for the Regional Committee at the French Ministry of Youth and Sport, for Ile de France. Coordinator at the World Equestrian Games in 2014 for the French Ministry of Youth and Sport. Coordinator for technical issues under the President of the FFE, Pascal Marry (September 2014); the president of the organizing committee of the Meeting for Riding in the French tradition, instructor of riding, director of the Horse and Riding collection at Belin Editions, Guillaume Henry (May 2016); former Ecuyer (Riding Master) at the Cadre Noir in Saumur; former Director of the Resource Centre at the National Riding School (ENE)/Cadre Noir de Saumur (IFCE). Historian of Educational science specializing in French riding schools, Patrice Franchet d'Espèrey (May 2016).

-Observations and interviews undertaken during introductory 'bauchiste' horse-riding training given by Patrice Franchet d'Espèrey, an expert at the National Riding School. The courses are open to registered independent riders (for a two-day paid-for course), at all levels from competition riders to amateur outdoor riding. My observation was carried out on April 7th, 2014 and combined with interviews with 10 trainees.

The purpose of this chapter is to shed light on the construction of an equestrian tradition, emerging from the choice of memory, certainly dependent on local historicity, but also on internationalized contemporary values. Like other European equestrian cultures (Thompson, 2010) I examine the process of heritage-creation within equestrian activities, which can be seen as both threatened by globalization (standardizing of the competition, the market economy, divergent leisure riding) and boosted by it, encouraging a reinterpretation of the work of the old masters through international tools (UNESCO), and a new sensitivity that flows from the new social uses of the horse that have spread throughout the West (emphasizing affection, pleasure and the construction of self). The preservation of a French equestrian tradition, which has required a reconstruction of its memory, has also opened the way for other European schools as seen by the 2015 inclusion of 'classical riding and the famous Spanish Riding School in Vienna' on the UNESCO intangible heritage list.

\section{A French equestrian tradition ? An historically built culture combining assimilation, resistance and invention.}

The French riding tradition has been identified as coming from a rich equestrian culture built on several centuries of history. To understand what it consists of, a historical overview is necessary. Like many equestrian cultures throughout the world (Thompson, 2010; Adelman, 2015; Obadovics and Kulcsar, 2015; Helgadottir, 2006; Franchet d'Espèrey, 2011), French horse-riding has been built on foundations that go back many centuries - in particular since the Renaissance period - by absorbing various international influences. It was indirectly influenced 
by Spanish riding, which stands out in Europe for having integrated, before any other culture did, the lightweight horse riding imported from the Arabs, which developed side by side, from the $11^{\text {th }}$ century onwards, with traditional heavyweight horse riding from the Middle Ages (Digard, 2007, 109). However, this Spanish influence did not spread directly into France, but into Italy, a true receptacle of Eastern and Western cultural influences which in the fifteenth century gave rise to a new form of riding, raised to the ranks of an equestrian art. The latter was then enveloped in deep societal transformations in which it was only a tool. In fact, the Renaissance permanently reorganized Western European societies through the construction of absolute monarchies and an aristocracy which redefined societal codes around the court and its followers (Duby (ed), 2007). In this context, riding moved away from having only military functions to redefining itself as an art, incorporating as many technical requirements as it did social projections. This art is expressed through new activities, shaping riding as it moved from its utilitarian military functions during the Middle Ages to the level of living sculpture, as sublimated movement striving for grace. The process fuses with the urbanization dynamics of the elites by integrating, according to the historian D. Roche, "the social demonstration of the civilisation of cities and courts", where the praise of the chivalrous mythology continues, between transfer and transformation, $(2011,175)$.

Thus, under the influence of riding masters such as Federigo Grisone, Giambattista Pignatelli in Naples or Cesare Fiaschi in Ferrare, new riding principles were introduced, based on the flexibility of horses, mobility on the voltes and speed $^{1}$, the crucible of a nascent European equestrian art. Equestrian academies were founded, in which 'all riders were forced to perfect their techniques' (according to La Guérinière, as quoted by the anthropologist J.P. Digard (2007, 122). French, German, English, Portuguese and Spanish riding masters came to these academies. This common European core which came to be before national specializations emerged partly explains current links between the four major European schools (French, Spanish, Portuguese and Austrian) ${ }^{2}$.

According to historian P. Franchet d'Espérey (2009), through a double process of appropriation and invention, the French school continues and exceeds the work of the Italians which was still centered around a military-inspired style of riding. The French school completed the redefining of the horse so as to highlight the elegance and the skill of an aristocratic art, through the works of Salomon de la Broue (who published a riding treatise in 1593) and Antoine de Pluvinel. From then on, riding, considered as performance for the upper classes in France as in other countries (such as Spain; see Thompson, 2012), took on wider social significance by directly incorporating the education of the elites. When at the end of the $16^{\text {th }}$ century Antoine de Pluvinel created an equestrian academy for the young French nobility in Paris, he associated it with the teaching of mathematics, literature, poetry, painting and music. Named as equerry to the future king Louis the $13^{\text {th }}$, he was put in charge of the king's equestrian instruction and dedicated his book "Le Manège Royal" (1623) (republished under the title "Instruction du roi en exercice de monter à cheval » (Instruction for the riding king; 1625) to the latter. d'Espèrey insists on the peculiarity of this work which offered "to the Prince a model of riding which, more than a metaphor of power, is a real mode of government. The horse mastered according to the

\footnotetext{
${ }^{1}$ These developments also met the new needs of fighting influenced by the development of firearms.

${ }^{2}$ These interactions also come more recently from the Portuguese master Nino Oliviera. Extensively inspired by methods of French riding - La Guérinière, Baucher - he greatly influenced the creation of Spanish (1973) and Portuguese (1979) riding Academies. Known internationally for his dexterity, he also became an inspiration for the riders at the Cadre Noir in Saumur and trained high-level French riders such as the famous Michel Henrique, who was the dressage technical adviser at the Cadre Noir in Saumur and the founder of the association for lightness in riding (Allège Idéal). The Spanish Riding School in Vienna meanwhile offers another European syncretism, combining Spanish horses with the French dressage method inherited from the eighteenth century works of La Guérinière and Austrian discipline.
} 
principles of learned riding reflects the capacity of its rider to manage the people" $(2009,59)$. Since then, the French radiance of the equestrian academy starts to exceed the former Italian hegemony in Europe.

If the metonymical relationship between riding and art manages to prevail in modern history and favored the creation of the equestrian academies in France from the end of the $16^{\text {th }}$ through the first half of the $17^{\text {th }}$ century (Roche, 2011, 183), its prodigious practices are far from unanimously recognized. Theories of riding in France are characterized by oppositions that can be violent, given the values and societal projections with which they are associated, lying somewhere in between military tool and object of distinction in urban society (Digard, 2007; Roche, 2011) stimulated by the nobility's weakening connections to military functions. In the eighteenth century, the equerry François Robichon de la Guérinière, who managed the royal arena at the Tuileries (since 1743), showed this determined search for grace in riding which had become the attraction of the court in his lavishly-illustrated book "L'école de cavalerie" (1733). As equitation had become an art dedicated to aristocrats who spent much less time on the battlefields now, in the Age of Enlightenment, technique was sometimes abandoned in favor of aesthetics. Although French was at the time currently read in the European courts, La Guérinière's text ${ }^{3}$ had been translated into Spanish in 1787, into German in 1791, into Italian in 1794 and into Swedish in 1828. But the English translation had to wait until 1994! His academy and his reputable book increase the radiance of the French riding in Europe especially, notably

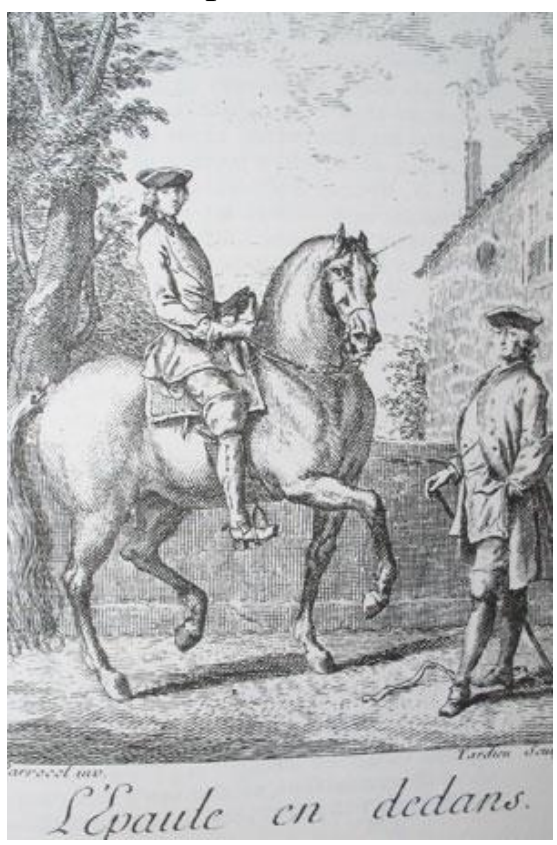
within the equestrian academy of Vienna which adopted its principle as a doctrine.

Nevertheless, his popularity was not unanimous in France. Since the army still needed a cavalry, in 1756, Louis XV founded, in order to counteract the hegemony of this riding of court, a military school in Paris with Colonel Auvergne as its chief equerry. It repositioned the horse in a strictly-utilitarian war role by trying to change the rider's sitting position when required to ride for long periods without tiring the mount (Henry and Oussedik, 2014, 50). Priority was given to balancing the horse/rider partnership rather than to an elegance which is often contradictory to these aims - especially in the straight and cambered position used by equerries from the $16^{\text {th }}$ to the $18^{\text {th }}$ centuries, crystallizing "the postulate of the righteousness of the ennobled body, [inspiring] the nobiliary social models " (Roche, 2011, 214) - figure 1.

Figure 1. The methods of La Guérinière based on the quest for elegance, coming from the rectitude position of the rider. "L'épaule en dedans" (http://www.communaute-tradition-equestre-francaise.org/images/technique/la_gueriniereecole_de_cavalerie-1733_0136.jpg).

The social and industrial revolution which marked Western Europe and France, at the end of the $18^{\text {th }}$ and $19^{\text {th }}$ centuries did not immediately weaken the societal place of the horse. On the contrary, horses were omnipresent throughout the continent and the social projections which were associated with them were strengthened. J.P. Digard reminds us that the number of horses in France reached its historical maximum of 3 million by 1840, numbers which were to remain relatively stable until the decline that began after 1935 (Digard, 2007, 143). This popularity was a sign of the fashionable status of 'the horseman' in a society in which the elite had to know

\footnotetext{
${ }^{3}$ It has been reedited six times in France from 1733 to 1769.
} 
how to ride. D. Roche asserts that between 1850 and 1900, three times more the titles on riding theories were published than over the three centuries of the ancien régime $(2015,78)$.

This increase did not particularly favor consensus. Once more, riding became deeply divided between two major schools. On the one hand, Antoine Cartier d'Aure, named Chief Ecuyer of the School of Saumur in 1847, emphasized the impulse and maximum extension of the gaits by pushing them on the hand "in the constant obsession of the movement forward in a natural balance" (Henry and Oussedik, 2014, 63). On the other hand, François Baucher proposed a more technical riding style, based on the relaxation of the horse, intent on replacing the instinctive strengths of the animal with transmitted strength, that is, the rider's commands. Through their numerous respective publications, these riding masters' continued the historical cleavage, contrasting a utilitarian and simplified military riding style to a more complex and technical one aimed at social representation. Because riding was an important part of French culture, an object used both to represent and conceptualize good practices, the d'Aure - Baucher opposition was replicated within society. People like the famous Alexandre Dumas, Georges Sand or Gustave Flaubert supported ideas associated with d'Aure ("Daurisme"), while the Duke of Orleans and the poets and writers Lamartine and Théophile Gautier preferred Baucher's approach ("Baucherisme") (Franchet d'Espèrey, 2009). This popularity overview the French society, notably with the publication of Baucher treaties in German in 1843 and 1844 and in English, in New York in the middle of the century (precise date unknown) :"New method of horsemanship: including the breaking and training of horses : with instructions for obtaining a good seat : illustrated". Baucher also gave equestrian representations and classes in several European cities (Berlin, Vienna, Milan, Venice...).

If French equestrian art was seen once again as being torn apart from the inside, it still contained considerable external influence. For instance, between the ages of 14-21, F. Baucher himself had been trained by his uncle in Italy, and thereby under Italian influences into the construction of his method ${ }^{4}$. However, by the end of the XIXth century, modernity was now coming from England. The popularity of English riding and its associated equipment rose. In this context, French riding adopted - not without some resistance, particularly from Colonel d'Aure - the rising trot, referred to as the 'English trot' which had been used in the UK since the $18^{\text {th }}$ century. This was assimilated in France to become widespread after the 1870 war, and was only allowed in the French army thanks to the General Alexis L'Hotte, who reformed the French cavalry according to modern military needs, adding it to the new cavalry laws of 1876 (Chaudun, 2016, 106). It is also interesting to note that in drafting this cavalry official law for his future methods, general L'Hotte was inspired by Austrian military riding but refused any German influence, for reasons of pride and politics, after the 1870 defeat.

This initial discussion attests to the plural nature of the French equestrian tradition, which has almost as many meanings as it has societal values. Although we cannot deny the existence of a French equestrian specificity, built on the foundation of five centuries of history from the Renaissance to the early $20^{\text {th }}$ century, it stems from a complex process of both assimilation of, and resistance to, influences from other European countries to which is has subsequently sent back ideas (Italy, Spain, Portugal, Austria, Germany, England, etc.). Therefore, the historical construction of French equestrian culture already emanates from interactions on local and global scales, leading to a specific type of syncretism, although largely restricted to Europe under the old regime. Therefore, when the First World War sounded the death knell for the reign of military riding, as trench warfare and new weaponry replaced the cavalry, the former

\footnotetext{
${ }^{4}$ The influence of the Italian equerry Frederico Mazzuchelli in his method, constitute still a debate between the Historians.
} 
pillar of military strength, French equestrian culture was not a single and indivisible whole. It was, on the contrary, composed of a number of movements and trends. Nonetheless, it did sustain some common centuries-old elements, closely associated to its background in an elite, martial and masculine art (Pickel-Chevalier \& Grefe, 2015).

\section{Has there been an American cultural revolution? French riding reconfigured through leisure and consumer society.}

It was the above-mentioned common characteristics which were shaken-up by the evolution of horse-riding in the twentieth century, especially under the influence of the new American model of a society built around leisure and consumption. While the changes brought about by the industrial revolution in the Western world seem to have sealed the fate of horses, as their energy was no longer needed to drive machines (Roche, 2008; Digard, 2009), the advent of a leisureobsessed society (Viard, 1982, 2000; Corbin, 2001), more specifically spawned in the USA (Aron, 1999), offers new horizons for equines. In a world becoming increasingly urbanized, horses, like dogs and cats before them, become synonymous with the natural world and are seen as sensitive companions, as famously suggested by Jean-Jacques Rousseau (Larrère \& Larrère, 1997; Pickel-Chevalier, 2014). Thus began the 'silent equine revolution' (Pickel-Chevalier \& Grefe, 2015) in a western world that was reinventing itself.

In reality this evolution began slowly at the end of the old regime in England, which saw the progressive movement of military riding into the sphere of emerging sports with the creation in 1750 of the first Jockey Club in Newmarket. The English model had to wait until the $19^{\text {th }}$ century before spreading into France, with the creation in 1833 of the Society supporting the improvement of horse breeds in France, partly under the influence of the British Lord Seymour who lived in Paris, and then the French Equine Society in 1865. Racing was a prelude to the emergence of equestrian sports, which were institutionalized in France in 1921 (with the creation of the French Equestrian Sports Federation), organized at international level with the founding, that same year, of the International Equestrian Sports Federation. Despite the rise of mixed-gender leisure practices since the $19^{\text {th }}$ century among the privileged classes, only male members of the armed forces were allowed to compete until 1952, especially in the Olympics Games (which has included equestrian sports since 1900), reflecting its significant inertia as a sport still firmly adhering to military tradition (from an interview with P. Marry, 2014).

Nonetheless, out-of-competition riding was now being enjoyed by both sexes and the number of riders slowly grew (Tourre-Malen, 2009). Furthermore, the switch from military tradition to sport and leisure progressively changed people's relationships to horses, expressed more clearly after the Second World War. The 1950s stood out due to the rise of the leisure and consumer society model, born thirty years earlier in the United States and introduced in France in a form restricted to the privileged classes during the roaring twenties (Bertho-Lavenir, 1999; Réau, 2011). From 1945 onwards, economic growth accompanied by and leading to an increasing population encouraged the spread of tourism and leisure and resulted in their 'popularization' (MIT, 2011). This growth led to social restructuring noticed by academics in 1962 (Dumazedier, Vers une civilisation du loisir?) and 1984 (Viard, Penser les vacances). Recreation, promoting the idea of 're-creation', became a social phenomenon determining the relationships between social groups and the land. In this context, leisure-based sports developed particularly quickly with encouragement from government that included them in their socioeducational programs (from 1962 to 1969). The latter, combined with a policy of providing sports facilities across the country (with some disparities), greatly contributed to the social diffusion of sport, especially as schooling became compulsory through age 16 (Terret, 2007).

Thus riding, which used to be elitist and military (Franchet d'Espèrey, 2009), joined this movement in a spectacular way. This was encouraged by the emotional and youth-orientated 
redefinition of horses, created first through literature and then through film aimed primarily at children (Pickel-Chevalier and Grefe, 2015) - in England (see for example the book Black Beauty by A. Sewell, 1877 and adapted for the screen in 1921) but most of all in the United States of America, with a long list of books and movies aimed at youthful audiences. Smoky the cow-horse by W. James, published in 1926 (Newberry Medal in 1927) and adapted for the cinema as early as 1933; The Red Pony, by J. Steinbeck published in 1933 and adapted for the screen in 1949 ; The Black Stallion by W. Farley, first volume published in 1941 (adapted for the screen in 1979); My Friend Flicka, by M. O'Hara, first volume published in 1941 and adapted for the screen in 1943; Misty of Chincoteague, by Marguerite Henry, published in 1947 and adapted for the screen in 1961; King of the wind by Marguerite Henry, published in 1948 (Newberry Medal in 1949) were major works on a long list that encouraged fundamental change in the role of the horse in society, redefined as a vector of social transgression and allowing for the success of the young rider. As such the horse, outwardly seen as a symbol of power and glory since antiquity (Roche, 2011), became redefined by the dual paradigm of subject of love and an object of transgression, embedded in processes of construction of the self (PickelChevalier and Grefe, 2015).

The conjunction of riding's arrival to the leisure and consumer society and the redefinition of the horse's place in society through a metamorphosed relationship with the animal encouraged an unprecedented growth in riding in France. The French Equestrian Federation had just over 20,000 registered members in 1949 (Chevalier V., 1998), a figure which rose to 145,071 in 1984 and 434,980 in 2000 before reaching a maximum of 706,449 in $2012^{5}$. Since then, the number has remained at a high level, but fell slightly to $673,026^{6}$ in December, 2015. Clearly this growth is linked to the broader context of the development of leisure activities: France had 1.8 million registered sportsmen and women in 1949, rising to 7.4 million in 1975 , and almost 15 million in 2015 (INSEE). However, the growth of riders is exponential: while the number of registered sportsmen and women across all sports federations has increased by $850 \%$ in a 62 year period, the number of FFE-registered members has increased by 3,500\% in the same timeframe. It became the third biggest federation at start of the 21 st century.

This extraordinary growth is largely based on young people taking up the sport, despite the fact that its high costs prevent its incorporation into routine school activity. However, the 1970s mark a key moment of change; the new spotlight on child psychology (Dolto, 1985; 1988) promoted a change in education and pedagogy and which horse-riding was quick to adopt. Even more important was the emergence of pony clubs with the creation in 1971 of the Pony Club of France, an institution funded with support from the National Stud (the organization responsible for breeding horses in France from the $17^{\text {th }}$ century through to 2010). Therefore, this federation appeared 50 years after the founding of the French Federation of Equestrian Sports (in 1921). For 16 years the world of French equestrian institutions has been divided into three independent entities: sport, tourism (created in 1963) and pony-riding. They did not join forces to create the French Equestrian Federation until 1987, yet retaining a certain level of autonomy with three separate delegations: equestrian sports, equestrian tourism and pony-riding (Chevalier V., $2011)^{7}$. This merger has benefited from the number of participants and in particular from pony clubs, the number of which increased six-fold between 1983 and 2000 (Tourre-Malen, 2009).

\footnotetext{
${ }^{5}$ This increase also results from the evolution of the federation, introducing new components.

${ }^{6} \mathrm{http} / / / \mathrm{www} . \mathrm{ffe} . \mathrm{com} /$ journaliste/Publications/Statistiques.

${ }^{7}$ In 1999, the articles governing the FFE were reviewed following the merger of the three entities which decided to each keep an element of their originality alive via the Management Committee. This included a Horse Committee, a Pony Committee, a Tourism Committee and a Competition Working Group.
} 
To this change in riding habits, via the phenomenon of a younger clientele, we can add the feminization of the sport. While riding and horses were identified as related to work or warfare (Roche, 2008), they were symbolically masculine and widely associated with virility. Yet in the 1960s, the sport became more associated with women. In 1963 the French equestrian federation already had more than 50\% female membership back in 1963 (Duret, 2001); figures reached more than $80 \%$ in $2009^{8}$. The Equestrian federation is now the number one femaledominated sporting federation in France. This phenomenon is certainly linked to the emancipation of women, which dates from the 1920s struggles for equal status and the recognition of skills at both a professional level and in sports and leisure activities (Defrance, 2011). The horse helped this change occur, as the French equestrian federation had been encouraging diversity in leisure practices as early as 1921 (Tourre-Malen, 2006). This early equality within a sporting federation probably emanates from the social profile of its members, coming from the privileged classes. Furthermore, early pioneers of women's sports came largely from the upper classes, where women were more likely to free themselves of normative constraints than within the working classes (Defrance, 2011).

Thus, at the beginning of the $21^{\text {st }}$ century, we find that horse-riding in France undergone changes in centuries-old characteristics; diverse influences have eased it into new societal functions, as an activity that encourages the personal development of children and teenagers as well as women's emancipation. In 2015, data reveal the new profile of French riders, 82\% female and coming mostly from the middle and upper-middle classes (Survey FFE, 2008 ${ }^{9}$ ) and showing an array of generations, as follows: $25.7 \%$ of children aged 10 and under; $25.3 \%$ of pre-teens and adolescents aged between 11 and 14;19\% of young people aged between 15 and 20 and $30 \%$ of adults aged 21 and above ${ }^{10}$.

\footnotetext{
${ }^{8}$ From: http://www.ffe.com/journaliste/Publications/Statistiques

${ }^{9}$ From: http://www.ffe.com/journaliste/Publications/Statistiques

${ }^{10}$ From: http://www.ffe.com/journaliste/Publications/Statistiques
} 
Immersed in a proven consumer society, today's riders do not have the same expectations as did riders in the 1950s. They are looking for recreation and self-fulfillment through sport but also affective relationships with the animal (Grefe and Pickel-Chevalier, 2015). Equestrian practices have thus seen major upheavals, further augmented by the parallel transformation of the riding schools from clubs to lucrative businesses (Chevalier V., 2016) that must seduce and keep their clientele. This commodification of riding has permanently changed the relationship with the rider, from a pupil to customer. Nonetheless, it has also allowed the perpetuation of riding in France (figure 2), by providing it with new economic and social stakes ${ }^{11}$. The diversity

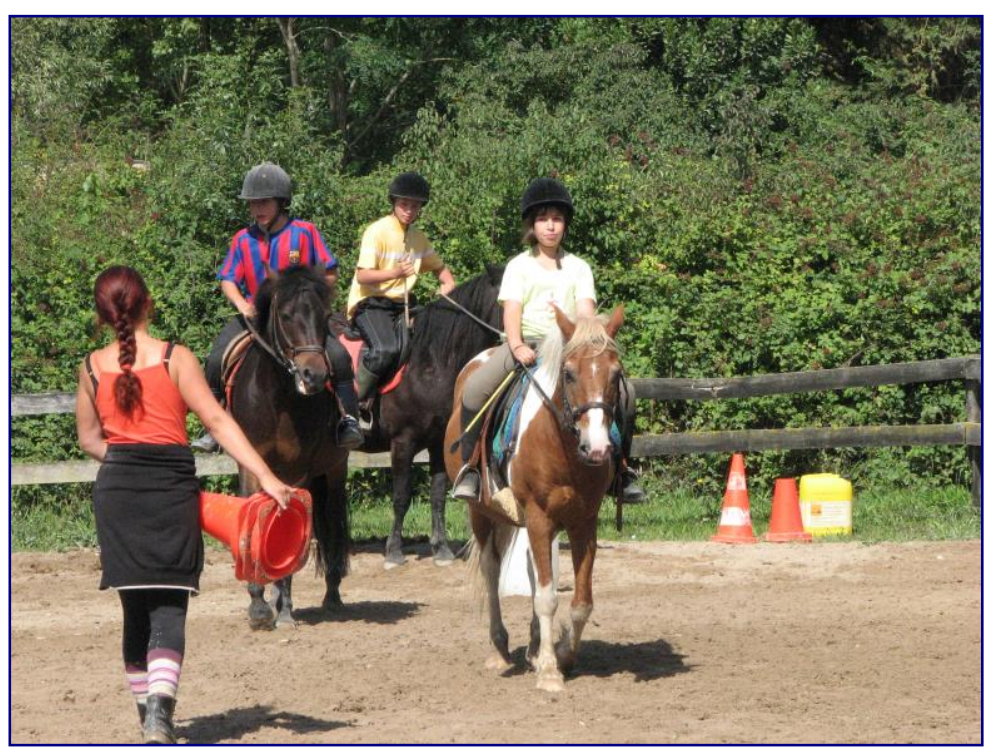

of expectations and the need for riding schools to become commercial in order to meet them has generated an unprecedented development of equestrian disciplines. There were 30 types of activities recognized by the FFE in 2015, combining classic approaches (show jumping, dressage, eventing) and the more or less recently institutionalized activities such as endurance, horseball, Camargue riding, etc.

Figure 2. France has maintained a lively equestrian culture by adapting to contemporary society, characterized by a significant change in rider profiles: $82 \%$ of FFE members are women and $70 \%$ are of young, aged 20 or under. Photo S. Pickel 2010.

This growth has unmistakably allowed the sustainability of the equestrian practice, and thereby of horse breeding in France. The graph of equine demography coincides largely with the development of equestrian leisure activities since 1989. As anthropologist J.P. Digard (2007) reminds us, the national herd had fallen from its high point of 3 million animals in $1935^{12}$ to just 269,000 in 1989. Since then, the number of animals has slowly begun its revival, in conjunction with the exponential surge in the number of the riders, from 214007 in 1990 to 673,026 in December $2015^{13}$. Today, the number of horses in the country is estimated at almost 1 million.

Thus, this second part of the present chapter demonstrates that France benefits from an equestrian culture which was born in the Renaissance and continue to thrive today, thanks to its ability to adapt to modern society, through assimilation, resistance and innovation. Nonetheless, the emergent culture is deeply heterogeneous, fed from different national and international influences and shaped through diverse and sometimes even opposing societal values. Therefore, French equestrian culture does not naturally converge within a single French riding tradition. The third part of this chapter will show that Equitation in the French tradition, as in the case of other equestrian traditions (Thompson, 2010) - and in fact all notions of traditions, in accordance with E. Hobsbawm and T. Ranger (2012) - has been socially constructed by those involved in it, for a variety of purposes. On the one hand, it has required a choice of memory

\footnotetext{
${ }^{11}$ In 2011, the IFCE estimated the number of jobs linked to the equestrian sector to be 38,900 full-time posts in the farming sector and 32,800 in the non-agricultural sector (IFCE, 2011, 15).

$1285 \%$ of them were drafthorses.

${ }^{13}$ From: http://www.ffe.com/journaliste/Publications/Statistiques
} 
(Sire, 1996). On the other, its creation did not emerge from a 'bottom-up' process, but on the contrary crystallized an 'institutionalization of the remembrance' (Hobsbawm and Ranger, 2012), supported by the IFCE, in a complex dialectic of local and global scales and dimensions.

\section{A tradition threatened or defined by globalization?: the inscription of Equitation in the French tradition as an example of UNESCO intangible heritage}

Through adapting to the expectations of leisure societies deeply influenced by new models, most of which were invented in the USA since the beginning of the $20^{\text {th }}$ century, French riding has succeeded in its perpetuation. However, a question remains for all the Europeans nations that have created a national equestrian Academy (Austria, France, Spain and Portugal) regarding the compatibility of this apparently heterogeneous riding with the preservation of older military practices: in light of all this diversity and growth, how can we identify the basis of a common culture, defined as a "set of ideal products available in a given social reality" (Lussaults, 2003, 216)?

Representatives of the IFCE expressed the need to preserve the French riding cultivated by the Cadre Noir of Saumur, to prevent it from disappearing in the face of the contemporary socioeconomic evolution of riding in France, further defending it 'against the potentially dangerous trend of standardization as a result of riding competitions and their regulations. Indeed, the international competition can lead to equestrian cultures being gauged only in terms of what matters, namely winning (which often boils down to a measurement of time or height). Highlighting the importance of the 'art and manner' of obtaining the result will draw attention to values other than utilitarianism, namely the elegance of the animal and its rider, understanding of the animal, the aesthetics of movements and good cooperation between animal and human being.' (From the registration file for the inclusion of the French riding tradition as part of UNESCO's intangible heritage, quoted from: UNESCO Nomination file no. 00440).

This danger, which comes despite the fact that the FEI integrated the precepts of L'Hotte in its dressage rules in 1929, is confirmed by the Director of the Resource Centre at the National Riding School, Bernard Maurel, who points out that "Sporting competition would prefer to see classical equestrian principles diluted under the influence of the race for better performance: the economy of the competitive system is based on the market for sporting horses and on the market for training competitors. In both areas, the priority for those involved is the result rather that the method". He points out that this race for competitiveness is headed up mainly by "the leading countries in the horse-sport market which are often those with the most influence in the world of competition (Germany, Holland, Belgium, Denmark etc.) and the least concerned with equestrian tradition ( with no public bodies, no national riding schools or academies). Germany however is the exception; there it is the animal protection league and some purists who complain about the excesses of the competition system.' (From an interview conducted in May 2016).

As such, if the French equestrian tradition was built, like most cultural objects, through a process of assimilation and syncretism, it is today all the more visible due to a claimed logic of resistance to international influences. However this does not mean that this equestrian tradition is limited to France only. Although those involved may feel threatened by certain developments in sports and leisure activities, it is nevertheless also supported by them. As Guillaume Henry, President of the organizing committee of the Meeting for Riding in the French tradition, reminds us, many riders around the world have adopted these techniques (from an interview 
conducted in May 2016). In addition, according to B. Maurel, those who enjoy such riding, 'are for most of them not professionals but enthusiasts, seeking a quality relationship with their horse, even during competitions, wanting to feel good sensations, a riding with accuracy and to develop a sort of ideal partnership with their horses' which has spread to many other countries, not just in Europe but also the United States, Canada and as far afield as Russia, Brazil or Iran (from an interview conducted in May 2016).

Therefore it is necessary to sketch out the complex relationship between the definition of a French equestrian tradition and globalization. The growth of equestrian leisure and sporting activities internationally (Pickel-Chevalier and Evans (dir), 2015), simultaneously generates an interest in equestrian cultures, but also the risk 'of losing significant landmarks, of the few controlling the many, of commercial or sporting dissidence' (B. Maurel, from an interview conducted in May 2016). The juxtaposition of these two phenomena leads to a need for identification and recognition. However, this process characterizes the very concept of a cultural heritage. To understand the issues involved, one should first look again at its definition. In 2015 the Council of Europe declared that it is defined as 'a group of resources inherited from the past with which people identify, independently of ownership, as a reflection and expression of their constantly evolving values, beliefs, knowledge and traditions. It includes all aspects of the environment resulting from the interaction between people and places through time'. It is thus less inherited than collectively constructed, as André Malraux already declared in 1935: 'the heritage is not passed on; it has to be conquered.' ${ }^{14}$ This institutional definition is reinforced by the academic O. Lazzarotti, who identifies heritage as ' $a$ set of attributes, performances and activities attached to a non-contemporary object (object, work of art, idea, testimony, building, site, landscape, activity) which is collectively deemed to be of both intrinsic current importance (where this object is representative of a legitimate history of our society's objects) and extrinsic (where this object includes values which support collective memory), which means it must be preserved and passed on' (Lazzarotti, 2003, 692). Everything is not thus heritage: its determination results from collective choices, joining a construction of the memory through the recognition of common identical milestones, as demonstrated by the sociologist N. Heinich (2009), professor G. Richards (2000) or the chief curator of historic monuments A.M. Sire (1996). Heritage therefore comes from an 'ideological dimension of memory' (Lazarrotti 2003, 692).

It succeeded and became a global phenomenon in its current form with the creation in 1972 of UNESCO's World Heritage Status, which was founded on the basis of both an aesthetic and monumental European heritage. Based on a Western principle of linearity of time (Lazarrotti, 2003, 692), this notion of heritage results in a distancing of the past compared to the present (Debray, 1999, 13) linked to a phenomenon of ring-fencing (Pickel-Chevalier, 2014). The past is therefore fixed so as to be protected in its current state and shared with future generations. This choice to ring-fence memory requires complicated relationships with culture which itself still needs to be dynamic. Indeed, it is defined either as 'the grouping together of ideal products available in a given social reality', or as 'a connection between the common world and members of a community' (Lussault, 2003, 216-217). Culture therefore implies a living, evolving organism. In some ways, heritage which fixes the assets of the distant past is then opposed to culture, enshrined in a contemporary time-frame and therefore subject to constant change, under internal but also external influences, augmented by globalization. This complexity in the relationship between heritage and culture is taken into consideration by UNESCO, with the creation of the intangible world heritage label, which attempts to answer this dilemma by

\footnotetext{
${ }^{14}$ International Congress of the writers for the defence of the culture, Paris, June $25^{\text {th }} 1935$.
} 
removing it. The convention relating to this was ratified in 2003 and did not become law until 2006. This UNESCO intangible heritage can be defined as follows: 'by intangible cultural heritage we mean the activities, ideas, expressions, knowledge and skills - as well as the instruments, objects, artifacts and cultural areas associated with them - which communities, groups and, where applicable, individuals recognize as part of their cultural heritage. This intangible cultural heritage, transferred from generation to generation, is constantly recreated by these communities and groups in line with their environment, their interaction with nature and their history, and provides them with a sense of identity and continuity, thus helping to promote respect for cultural diversity and human creativity [...]. ' (Convention for safeguarding intangible cultural heritage).

This new concept includes the combined ideas of a heritage passed from generation to generation, yet one that is part of contemporary culture, constantly recreated by communities and contributing to cultural diversity and human creativity. In itself, the intangible heritage of UNESCO crystallizes the relationship between local and global identification and radiance. But the question raised by intangible heritage is how to succeed in reconciling preservation, which implies a certain inflexibility, with adaptation to a live, evolving society. Certainly, the Intangible Cultural Heritage of Humanity list from UNESCO seems, given its definition, an appropriate tool to preserve a living equestrian culture, as was well understood by IFCE representatives. However, the UNESCO convention requires above all a prior identification of the culture concerned (Grenet, 2011), and the community related to it. The latter may correspond to different criteria because the 2003 agreement remains deliberately vague in order to suit various situations (Bortlotto, 2011). Nevertheless, in 2006 experts brought together in Tokyo by UNESCO formulated an unofficial definition of communities as 'networks of people whose sense of identity or links stem from a shared historical relationship, rooted in the practice and transmission of, or attachment to, their intangible cultural heritage' (UNESCO-ACCU, 2006). Community involvement is central to understanding the specialty of an intangible cultural heritage, which is not a simple category of heritage objects but a category of public cultural activities (Hottin, 2011). In the French case, the culture concerned has not been restricted to one riding style, but to a French 'tradition'. This concept, closely associated with intangible heritage, is less inherited than socially built. According to Lewis and Hammer, 'In the dictionary sense of word, tradition constitutes a set of inherited patterns of belief and practices that have been transmitted from generation to generation. In another sense, tradition can rest simply on the claim that certain elements are roots from the past' (Lewis and Hammer, $2007,1)$. This means that tradition crystallized a desire to 'construct or fabricate a relationship between the past and the present' (Thompson, 2010, 526), which does not imply an absence of interruption but, on the contrary, a distance from the past allowing choice and reinterpretation of the former used as a present goal.

In the context of the French riding tradition, officials from the IFCE responsible for the labeling project within the French Ministry of Culture and Communication initially defined their community as those riders who recognized the principles set out by General L'Hotte, because of its double baucheriste and d'auriste ${ }^{15}$ inheritance. Chief Riding Master of the Cavalry School in Saumur from 1864 to 1872, he was successively the pupil of both masters and suggested a French riding style which is a synthesis, combining 'the ambition of the forward movement, which has to show itself constant' and 'the harmony of the movements which show the correct use of the aids, and the lightness which ensues from it' (quoted in Henry and Oussedik, 2014, 78). His doctrine about which he theorized in a book published after his death (Questions

\footnotetext{
${ }^{15}$ It is also part of the more ancient tradition developed by La Guérinière, La Broue and Pluvinel.
} 
Equestres, 1906) was adopted by the Cavalry School in Saumur and promoted a consensus to be referred to in the filiations of the former two rivals. L'Hotte is also responsible for the famous principle: calme, droit, en avant (quiet, straight, walk-on) which is still very well-known by all French riders practicing the sport in clubs.

If this doctrine is observed by many riders around the world, it has especially been adopted by the Cadre Noir in Saumur and the National Riding School (ENE) created in 1972 and connected with the Ministry of Youth and Sport. The mission of the institution is to train future riding teachers and champions through several programs, providing them with technical and theoretical knowledge and which is also disseminated through public presentations and shows. However, in order not to lock this tradition into the past, the managers at the Cadre Noir of Saumur (IFCE), in association with the French Ministry of Culture and Communication, have chosen to broaden the definition of French riding tradition. Instead of restricting it to a fixed heritage, drawn from past centuries, they have elevated it to a philosophy on the relationship between the horse and rider, open to the future. As such, French equestrian culture under UNESCO's Intangible Cultural Heritage label corresponds to the following definition:

'Riding in the French tradition is a school of horse riding that emphasizes harmonious relations between humans and horses. The fundamental horse-training principles and processes are guided by non-violence and a lack of constraint, blending human demands with respect for the horse's body and mood. Knowledge of the animal itself (physiology, psychology, anatomy) and human nature (emotions and the body), are complemented by a horseman's state of mind that combines skill and respect for the horse. Fluidity of movements and flexibility of joints ensure that the horse participates in the exercises without coercion. Although practiced throughout France and elsewhere, the most widely known community is the Cadre Noir of Saumur, based at the National Riding School. The common denominator among riders is the desire to establish close relations with the horse, build mutual respect and work towards achieving 'ightness'. Cooperation between generations is strong, with respect for the experience of older riders, galvanized by the enthusiasm of younger riders. The Saumur region is also home to instructors, horse breeders, craftspeople (saddlers, boot-makers), veterinary services and blacksmiths. Frequent public displays and galas hosted by the Cadre Noir of Saumur help to sustain the visibility of horse riding in the French tradition. 16

Therefore, the definition primarily corresponds to a 'kind of ethics for the relationship between man and horse', and 'the fairly balanced relationship between animal and man which deals with contemporary concerns with regard to the status of animal in society', highlighted by P. Liévaux, Director of Heritage at the Ministry of Culture and Communication (from an interview conducted in 2014). He stressed that "what interests UNESCO is the anthropological value of the activity, what this brings to man, what it means for his relationship with the animal and more generally in its positioning in society and the universe' (from an interview conducted in 2014).

This inclusion of the French riding tradition in the UNESCO heritage list is therefore the result of strong links between local and global arenas. Indeed, it would never have been included if it were only to represent the elitist equestrian style favored by the Cadre Noir in Saumur. The fact that it is taught and shared are the true essence of its recognition as an example of world heritage (and the aspect which has caused the greatest fear among UNESCO experts, as Sylvie Grenet, responsible for submitting the application at the Ministry of Culture, reminds us http://insitu.revues.org/9675). This search for universalism is also expressed in the decision not to associate the French riding tradition to a specific breed of horse, such as the Selle Français,

\footnotetext{
${ }^{16} \mathrm{http} / / / \mathrm{www}$. unesco.org/culture/ich/index.php?lg=en\&pg=00011\&RL=00440
} 
which is the most commonly used breed at the Cadre Noir. As B. Maurel points out, 'The French equestrian tradition is not linked to a breed, but to a whole range of techniques, and especially to a philosophy inherited from its history' (May 2016). The fact that this riding is not associated with a local breed favors its deterritorialization. Indeed, as practiced everyday by the Ecuyers at the Cadre Noir in Saumur, these riding principles make a claim of suitability for any type of rider anywhere in the world. This phenomenon is also visible in the "baucheriste" riding courses led by Patrice Franchet d'Espérey. Our observations and interviews conducted on April $7^{\text {th }} 2014$ with 10 participants (Figure 3) allowed us to witness the variety of profiles among the participating riders from a range of different countries, men and women, most of whom are amateurs at dressage (but do sometimes participate in competitions), jumping or outdoor riding, on a variety of breeds (Selle Français, English thoroughbreds, Iberian breeds, Icelandic horses, ponies). They are however all horse owners, aiming for improved relationships with their horses. For example, Serge ${ }^{17}, 47$ years of age from Sarreguemines, owner of 20 Icelandic horses and who enjoys outdoor riding, said he enrolled in the course so as 'to learn how to apply our French riding style when training my Icelandic horses with an ethological philosophy.' Julie, 38 years of age, is an instructor who participates in competitions (CCE) and manages a ridingschool and pony-club in Versailles. She signed up for the course 'to progress, learn and be more accurate and fair, in a riding style that takes into account the welfare of the horse.' Anna, 39 years of age, is a German amateur dressage rider (not in competitions) and also enjoys outdoor riding. She attended the course in order to find 'a better way of working with my horses, based on lightness.'

\section{Figure 3. The Baucheriste method, suggested by Patrice Franchet d'Espèrey, has attracted new interest from amateur horse riders and owners through a reinterpretation in the search for an ethological approach - seeking a better relationship with one's horse, mutual trust, respect and welfare (photo $S$. Pickel, 2014).}

This survey also allows us to

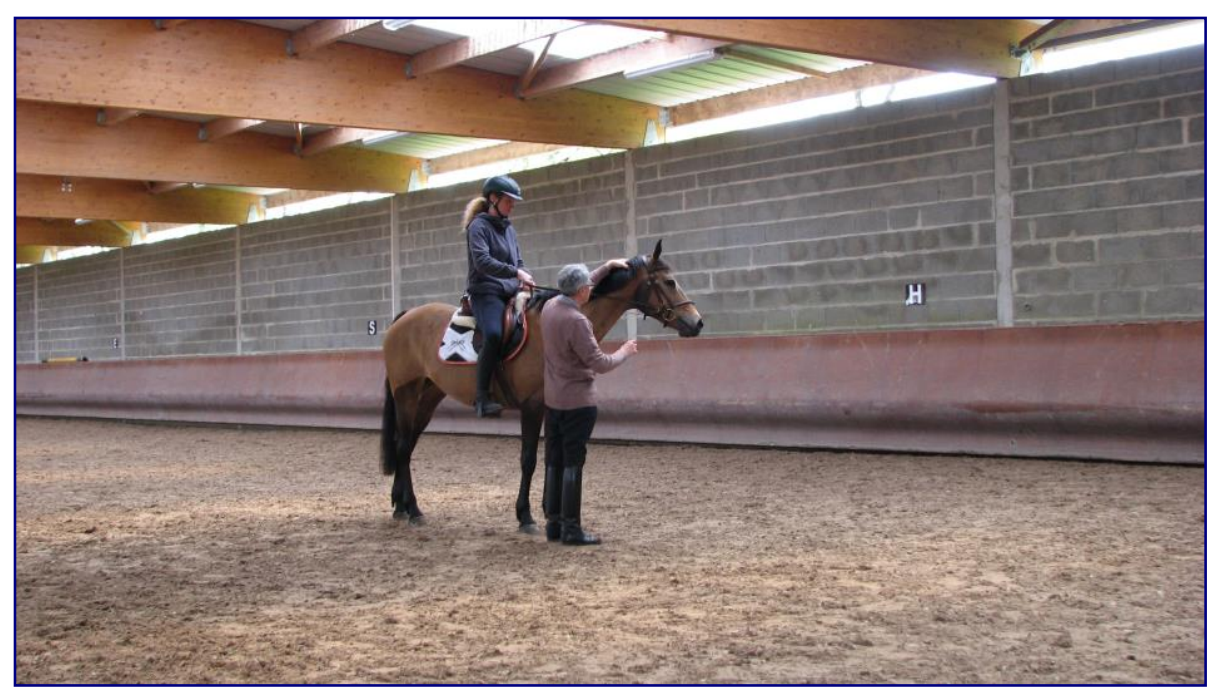
notice that rather than standing out in response to contemporary and international philosophies in relation to riding, the French tradition has instead partially adopted them. In effect, the riders participating in the course almost systematically adopt the baucheriste approach, which is one of the fundamental components of the French tradition, aiming for a riding style which promotes the respect and welfare of the horse. Some even consider this to be a 'French-style ethology'. This phenomenon illustrates the persistent nature of international influences, visible even in the process by which we identify French riding. Like any tradition, its definition is a combination of both the present and the past (Thompson, 2010), constructed on the basis of elements chosen from different time periods. For example, the trend of American 'whisperers', constituting an empirical approach based on behavioral observations identified towards the end of the $1990 \mathrm{~s}^{18}$, has bred a double reception in France, just as the ambiguous relationship which

\footnotetext{
${ }^{17}$ The names have been changed so as to afford anonymity to those students interviewed.

${ }^{18}$ Particularly following the publication of the novel The Horse Whisperer by Nicolas Evans (1995), adapted for the screen by Robert Redford and a box-office hit in 1998.
} 
links French society to American society, a cross between fascination and resistance. On the one hand, it has contributed to the revolution in relations with the animal, all the more assimilated and supported by today's largely female riding population (in 2001, women already accounted for $74 \%$ of registered riders in France) in search of a more inclusive model for their relationships with horses that is not strictly limited to riding (Pickel-Chevalier and Grefe, 2015). On the other hand it has generated - no doubt in part due to a 'nationalist' reaction - a rediscovery of classical French riders, seen as a response to the American fashion. Guillaume Henry notes that the growth in publications by American 'whisperers' has coincided with the reissue of methods espoused by the old French masters (La Guérinière, Baucher, L'Hotte and many new books explaining the art of those traditional Masters). This duality is also illustrated in the popular Cheval Magazine (the most widely-read non-professional equestrian magazine in France) which each month devotes a double page spread to a different new master, by which they mean a 'whisperer', followed by a double page spread about a former and classical master, most often French. The new fashion, in the wake of American influence, thus encourages the rediscovery of a national heritage which had been largely ignored or neglected. This situation also arises from the fact that, according to Guillaume Henry, 'the French have adopted the American horsemen's philosophy, but not generally the American horsemen themselves, as in the German case.'

If the approach based on respect and patience has not left French riders indifferent, the American culture of performance and riding has not been adopted in France with the same enthusiasm as in other European countries ${ }^{19}$. Yet it has encouraged French methods, such as the school set up by Nicolas Blondeau, who claims to apply a French ethological method based on an adaptation of the writings by the French classical masters, and especially those of General L'Hotte, Baucher or Pluvinel ${ }^{20}$.

Thus, the popularity of American whisperers has, through reaction, encouraged a simultaneous process of rediscovery of works by the old masters and their reinterpretation through a more general philosophy of respect for the animal and a search for cooperation without violence, clearly cemented in the definition of the French riding tradition as registered in UNESCO's intangible heritage list. This perception was confirmed by Patrice Franchet d'Esperey, who claimed: "The question of the welfare of the horse has always been in the French classical treaties, but they had been forgotten and ignored since the end of the XIXth century" (from an interview conducted in May 2016). L'Hotte himself made the following statement of the underlying principle of his methods: "The spirit of the horse must be the first and constant concern of the rider. He must sacrifice everything to the calm and trust of his horse" (Questions Equestres, 1906).

\section{Conclusion}

French equestrian culture is therefore built on a foundation comprising six centuries of history, through a process of assimilation of international trends, resistance to change and inventions through syncretism. Although it has indirectly included Eastern influences in its genesis, it has been particularly initially influenced by inter-European exchanges, helping to create a true cultural melting pot; this explains why so many similarities exist today, for example, in the

\footnotetext{
${ }^{19} \mathrm{La}$ Cense, the main French riding center based on this model of American horsemen, today offering an approach including a syncretism that associates the methods of whisperers within a very French riding style, totally differentiated from western riding, more attuned towards leisure and competition of jumping and dressage.

${ }^{20}$ Nicolas Blondeau's method is recognized by the IFCE, by the FFE and by the racing world. He has published several books on his method of ethological breaking-in of horses.
} 
names given to the movements taught at the top four European riding academies (France, Austria, Portugal and Spain). This cultural base has however been profoundly modified over the course of the $20^{\text {th }}$ century, under the new American hegemony, encouraging the inclusion of horse riding in the leisure and consumer society, as well as the reinvention of the humanhorse relationship through the dream of an alter ego. Once again, horses and horse riding have become vehicle and instrument of deeper societal evolution. If they have been symbols of the aristocratic elite since ancient times, a fact greatly enhanced by their inclusion in the civilization of the courts which begun in the Renaissance, they have also taken on new societal uses by being redefined through the dual paradigm of a subject of love / object of transgression that promotes human self-fulfillment (Pickel-Chevalier and Grefe, 2015).

French equestrian culture is not an exception but is fed by the same changes and patterns that are pervasive throughout the Western world, transforming traditional symbols linked to riding, as evidenced by the many cultural works (novels, films) reproduced in America, Canada, Europe and Australia (Pickel-Chevalier and Grefe, 2015). This change, which has led to the perpetuation and even the unprecedented boom in equestrian activities in France, nonetheless raises issues regarding the balance between the dynamism of a living and constantly reinvented culture and the preservation of a heritage threatened with becoming obsolete. In response to this challenge, IFCE managers, with the support of the Ministry of Culture and Communication, turned to a tool to guarantee interactions at local and global scales, the UNESCO intangible heritage list. They managed to open the way for the recognition of a form of riding that could be elevated to world heritage status by building tradition with international dimensions, based on a philosophy combining as inherited classical method (General L'Hotte) and a contemporary sensitivity (respect for the non-human animal, aiming for cooperation without violence). The French tradition of riding is clearly a construction of memory, based on the creation of selected links between the past and the present, through a constant dialectic between local and international arenas that feeds it and infuses it with energy, part of a globalization process which at its best is vector of cultural enrichment and innovation.

\section{References:}

Adelman, M., 2015, "Riding for our lives: women, leisure and equestrian practices in Brazil today", in: Pickel-Chevalier, S. and Evans, R., 2015, Cheval, Tourisme \& Sociétés/ Horse, Tourism\&Societies, Mondes du Tourisme, Hors série, 2015, Paris, pp. 50-63.

Aron, C.S., 1999, Working at play: A history of vacations in the United States, Oxford University Press.

Babelon, J.P. and Chastel, A., 1994 (réed), La notion de patrimoine, Liana-Levi Editions, Paris. Bertho-Lavenir, C., 1999, La roue et le stylo. Comment nous sommes devenus touristes, Editions Odile Jacob, Paris.

Bortolotto, Ch. (ed), 2011, Le patrimoine culturel immatériel. Enjeux d'une nouvelle catégorie, Maison des sciences de l'homme, Paris.

Chaudun, N., 2016, Un centaure au crépuscule, Alexis L'Hotte, Actes Sud, coll. Arts équestres, Paris.

Chevalier, V, 2016, « Des entreprises marchandes dans l'univers associatif sportif. Le cas des établissements équestres » in : Sociologie pratique, 2016/2, n³2, pp. 55-64.

Chevalier, V., 2011, "Conflits dans le monde sportif. Le cas de la Fédération Française d'Équitation ", La Vie des idées, 25 novembre 2011. ISSN : 2105-3030. URL : http://www.laviedesidees.fr/Conflits-dans-le-monde-sportif.html

Chevalier V. et Dussart B., 2002, «De l'amateur au professionnel : le cas des pratiquants de l'équitation », L'Année sociologique 2/ 2002 (Vol. 52) , p. 459-476. 
Convention for safeguarding intangible cultural heritage, http://www.unesco.org/new/en/santiago/culture/intangible-heritage/convention-intangiblecultural-heritage/

Corbin, A., 2001, L'avènement des loisirs, 1850-1960, Champs-Flammarion, Paris.

Debray, R., 1999, L'Abus monumental ? Actes des Entretiens du Patrimoine, Fayard, Paris.

Deci, E. and Ryan, R.. 2000, "Self-determination theory and the facilitation of intrinsic motivation, social development and well-being », American Psychologist, vol.55, $\mathrm{n}^{\circ} 1$.

Defrance, J., 2011. Sociologie du sport. La découverte, Paris, France.

Deprest, F., 1997, Le tourisme de masse. L'écologie face au territoire, Belin, Paris.

Digard, J.P., 2007. Une histoire du cheval. Actes Sud, Paris, France.

Digard, J.P., 2009. « Le cheval, un animal domestique au destin exceptionnel », Arts Equestres, Revue 303 Arts, recherche et créations, 2009, 12-19.

Dollfus, O., 2007, La mondialisation, Presses des Sciences Po, Paris.

Dolto F., 1988, La cause des adolescents, Robert Laffont, Paris

Dolto F., 1985, La cause des enfants, Robert Laffont, Paris.

Duby, G., (ed), 2007, Histoire de la France, Des origines à nos jours (1 ${ }^{\mathrm{er}}$ édition 1971), Paris, Larousse, coll. "Bibliothèque historique".

Dumazedier, J., 1962. Vers une civilisation du loisir ? Ed. Seuil, Paris, France.

Duret, P., 2001, Sociologie du sport, Armand Colin, Collection «Dynamiques », Paris. Durand, P., 2008, L'Équitation française, Actes Sud, 210 p

FFE, 2015, Etudes et enquêtes chiffrées, http://www.ffe.com/journaliste/Publications/Statistiques

Helgadottir, G., 2006, "The culture of horsemanship and horse-based tourism in Iceland", Current Issues in Tourism, vol 9, n 6 .

Franchet d'Espèrey, P. (ed.), 2011. L'équitation française, Le Cadre Noir de Saumur et les écoles européennes, Doctrines, traditions et perspectives, Lavauzelle, France.

Grefe, G. and S. Pickel-Chevalier, 2015, "De la transformation des établissements équestres en France : une offre fragilisée ou favorisée par l'évolution sociétale de l'équitation? » In PickelChevalier, S. and Evans, R., 2015, Cheval, Tourisme \& Sociétés/ Horse, Tourism\&Societies, Mondes du Tourisme, Hors série, 2015, Paris, 136-149.

Obadovics, C and Kulcsar L., 2015, "Horse industry in Hungary: the rebirth through tourism and leisure?" in Pickel-Chevalier, S. and Evans, R., 2015, Cheval, Tourisme \& Sociétés/ Horse, Tourism\&Societies, Mondes du Tourisme, Hors série, 2015, Paris, 126-135.

Grenet, S, 2012, «L'inscription de l'équitation de tradition française à l'UNESCO »In Situ, mis en ligne le 31 juillet 2012, consulté le 10 octobre 2015, http://insitu.revues.org/9675

Hanna, W., 1972. "Bali in the seventies. Part I. Cultural Tourism" American universities field staffs reports. Southeast Asia Series, 20/2, pp.1-7.

Heinich, N. 2009, La fabrique du patrimoine. De la cathédrale à la petite cuillère, Paris : Edition de la maison des sciences de l'homme.

Henry, G. and Oussedik, M., 2014. Une histoire de l'équitation française, Paris : Belin.

Hobsbawm, E. and Ranger, T. (ed). 2012. The invention of tradition, Cambridge: Cambridge University Press.

Hottin, Ch, 2011, Le patrimoine culturel immatériel, premières expériences en France, Babel, International de l'Imaginaire, Actes Sud.

IFCE, 2011. Panorama économique de la filière équine. Les haras nationaux, Haras du Pin, France.

Institut National de la Statistique et des Etudes Economiques (INSEE), 2013. http://www.insee.fr/fr/regions/.

Larrère, C. et Larrère, R., 1997, Du bon usage de la nature, Pour une philosophie de l'environnement, Flammarion, collection Champs-Essai, Paris. 
Lazzarotti, O., 2011, Tourisme et patrimoine, Histoire, lieux, acteurs et enjeux, Belin, Paris. Lazzarotti, O., 2003, «Patrimoine », in Lévy J.\& Lussault M.(dir), 2003, Dictionnaire de la géographie et de l'Espace des sociétés, Belin, Paris, 692-693.

Lazzarotti, O. et Violier, Ph, 2007, Tourisme et patrimoine. Un moment du monde, presses universitaires d'Angers, Angers.

Lévy, J. (dir), 2008, L'invention du monde. Une géographie de la mondialisation, Presses des Sciences Po, Paris.

Lévy, J.\& Lussault M.(dir), 2003, Dictionnaire de la géographie et de l'Espace des sociétés, Belin, Paris.

Lewis J.R. and Hammer O., 2007, The invention of sacred tradition, Cambridge University Press, UK.

Lussault, M., 2003, "Culture », in Lévy, J. et Lussault M.(dir), 2003, Dictionnaire de la géographie et de l'Espace des sociétés, Belin, Paris, 216-217.

MIT, 2002, Tourisme 1, Lieux communs, Belin, Paris.

MIT, 2005, Tourisme 2, Moment de lieux, Belin, Paris.

Mitford, N, 1959, The Tourist, Encounter, n73, 3-7.

Pickel-Chevalier, S. and Evans, R., 2015, Cheval, Tourisme \& Sociétés/ Horse, Tourism\&Societies, Mondes du Tourisme, Hors série, 2015, Paris, 229 p.

Pickel-Chevalier, S. and Grefe G., 2015, «Le cheval réinventé par la société des loisirs en Occident : une mythologie révolutionnée ? (XVIII-XXIe) », in : Pickel-Chevalier, S. and Evans, R., 2015, Cheval, Tourisme \& Sociétés/ Horse, Tourism\&Societies, Mondes du Tourisme, Hors série, 2015, Paris, pp.26-49.

Pickel-Chevalier, S., 2015, "Can equestrian tourism be agent of sustainable tourism development in France ?", Loisir et SociétélLeisure and Society, Volume 38, issus 1, Trois Rivières, Canada, 2015, pp. 110-134.

Pickel-Chevalier, S.,2014, L'Occident face à la nature, à la confluence des sciences, de la philosophie et des arts, Cavalier Bleu, coll. Idées Reçues, 2014.

Porter, M, 1999, La concurrence selon Porter. Editions Village Mondial, Paris, Ed. originale : On Competition. Boston, Harvard Business School Press.

Rallet, A. et Torre, A., (dir), 1995, Economie Industrielle - Economie Spatiale, Economica, Paris.

Réau B., 2011, Les Français et les vacances, Editions du CNRS, Paris.

Richards Greg, 2000, "Tourism and the World of Culture and Heritage », in : Tourism Recreation Research, Volume 25, Issue 1, 2000, p 9-17), equine economy in France", in Evans Roche, D.. 2015. La culture équestre de l'Occident XVI-XIXe s : Connaissance et passion.

Paris : Editions Fayard.

Roche D., 2008, Le culture équestre de l'Occident XVI-XIXe s, Editions Fayard, Paris.

Roche, D.. 2011. La culture équestre de l'Occident XVI-XIXe s : La puissance et la gloire, Paris : Editions Fayard.

Sire, M.A., 1996 (réed 2008), La France du patrimoine. Les choix de la mémoire. Culture et société, Découvertes-Gallimard, Paris.

Terret, T., 2007. Histoire du sport. PUF, collection Que sais-je ?, Paris, France.

Thompson K., 2010, "Narratives of Tradition: The Invention of Mounted Bullfighting, as the "newest but also the oldest", Social Sciences History, 34/4, 523-562.

Thompson K., 2012, "Classy performances: the performance of class in the andalusian bullfight from horseback (rejoneo)", Journal of Spanish Cultural Studies, http://www.tandfonline.com/loi/cjsc20

Tourre-Malen, C., 2006. Femmes à cheval. La féminisation des sports et des loisirs équestres : une avancée? Belin, Paris, France. 
Tourre-Malen, C., 2009. « Évolution des Activités Équestres et Changement Social en France à partir des années 1960 ». Le Mouvement Social, 229, La Découverte, 41-59.

Viard, J., 1982, Penser les vacances, Actes Sud, Paris.

Viard, J., 2000, Court traité sur les vacances, les voyages et l'hospitalité des lieux, Editions de L'Aube, Paris.

Wolfrom, J, 2014, La labellisation a-t-elle pour dessein d'éviter les travers de l'uniformisation? Le cas de l'inscription de l'équitation de tradition française au patrimoine culturel immatériel de l'UNESCO, mémoire de Master 2 Tourisme et Loisirs Sportifs, Campus de Saumur, ESTHUA, Université d'Angers. 